\title{
DIGITALISASI KURIKULUM MULTIKULTURAL DI STAI AI-KHAIRAT PAMEKASAN
}

\author{
Mo'tasim \\ STIT Al - Ibrahimy Bangkalan \\ Mu’tasim@gmail.com
}

\begin{abstract}
STAI Al-Khairat at least through its curriculum has done and applied Multicultural values both naturally and through digital media learning. Although multicultural looks hidden, it is not directly mentioned terminologically in concept or in learning. But explicitly or naturalistic multicultural values exist and are taught even applied in the system of everyday student life. In curriculum of multicultural value education almost taught every semester on religious studies, such as introductory study of Islam, tafseer, hadith, and tasawwuf morality. Values like; al-rahmah (affection), hablunminannas (humanist), al-musawaroh (democracy / prioritizing dialogue), al-a'dl (Justice), al-tasamuh (tolerance), al-ta'ruf (togetherness), al-ta'awun (assistence), as-salam (peace), al-ta'adudiyat (plural), al-'afwu (forgiveness), al-ikhsan (positive thingking), natural and systemic (discipline / honest) discipline has been present in the campus environment.
\end{abstract}

Keywords: Digitalization, multicultural curriculum, higher education, STAI Al-khairat Pamekasan.

\begin{abstract}
Abstrak
STAI Al-Khairat setidaknya melalui kurikulumnya telah melakukan dan menerapkan nilai Multikultural baik secara natural maupun melalui pembelajaran media digital. Meskipun multikultural terlihat hidden atau tersembunyi tidak secara langsung disebutkan secara terminologis dalan konsep maupun dalam pembelajaran. Tapi secara eksplisit atau naturalistic nilai-nilai multikultural ada dan diajarkan bahkan diterapkan dalam sistem kehidupan mahasiswa sehari-hari. Secara silabi/kurikulum pendidikan nilai multikultural hampir diajarkan setiap semester pada kajian keagamaan, seperti pengantar studi islam, tafsir, hadist, dan akhlak tasawwuf. Nilai-nilai seperti; al-musawah (kesetaraan/persamaan), al-rahmah (kasih sayang), hablunminannas (humanis), al-musawaroh (demokrasi/mendahulukan dialog), al-a'dl (Keadilan), al-tasamuh (toleransi), al-ta'ruf (kebersamaan), al-ta'awun (tolong menolong), as-salam (kedamaian), al-ta'adudiyat (plural), al-'afwu (inklusif), alikhsan (positive thingking), al-amanah (disiplin/jujur) secara natural dan sistemik telah hadir di lingkungan kampus.
\end{abstract}


Kata Kunci : Digitalisasi, kurikulum multikultural, pendidikan tinggi, STAI Al-khairat Pamekasan.

\section{Pendahuluan}

STAI Al-Khairat adalah salah satu perguruan tinggi Islam yang memiliki unsur dan sifat multikultural. Nilai Multikultural kampus yang secara geografis berada di antara tiga Pesantren besar di Kabupaten Pamekassan ini setidaknya terlihat pada kurikulum yang diterapkan. Kurikulum 232/U/2000 yang menekankan kepada pendekatan kurikulum KBK dirancang dan dilaksanakan dengan tetap mempertimbangkan nilai kemanusian atau nilau universalitas dan hitrogenitas mahasiswa. Sehingga mahasiswa yang datang dari berbagai daerah di Nusantara merasa dihormati dan mendapat perhatian sama.

Perjalanan perubahan kurikulum pendidikan tinggi di Indonesia. Tahun 1994 melalui Keputusan Menteri Pendidikan dan Kebudayaan Republik Indonesia Nomor 056/U/1994 tentang Pedoman Penyusunan Kurikulum Perguruan Tinggi dan Penilaian Hasil Belajar Mahasiswa, dimana kurikulum yang mengutamakan ketercapaian penguasaan IPTEKS, oleh karenanya disebut sebagai Kurikulum Berbasis Isi. Pada model kurikulum ini, ditetapkan mata kuliah wajib nasional pada program studi yang ada. Kemudian pada tahun 2000, atas amanah UNESCO melalui konsep the four pillars of education, yaitu learning to know, learning to do, learning to be dan learning to live together (Dellors, 1998). Indonesia merekonstruksi konsep kurikulumnya dari berbasis isi ke Kurikulum Berbasis Kompetensi (KBK). Kurikulum era tahun 2000 dan 2002 ini mengutamakan pencapaian kompetensi, sebagai wujud usaha untuk mendekatkan pendidikan pada kondisi pasar kerja dan industri. ${ }^{1}$

\footnotetext{
${ }^{1}$ Tim, Pedoman penyusunan KKNI Kemenag Diktis Kopertais Wilyah IV Surabaya.
} 


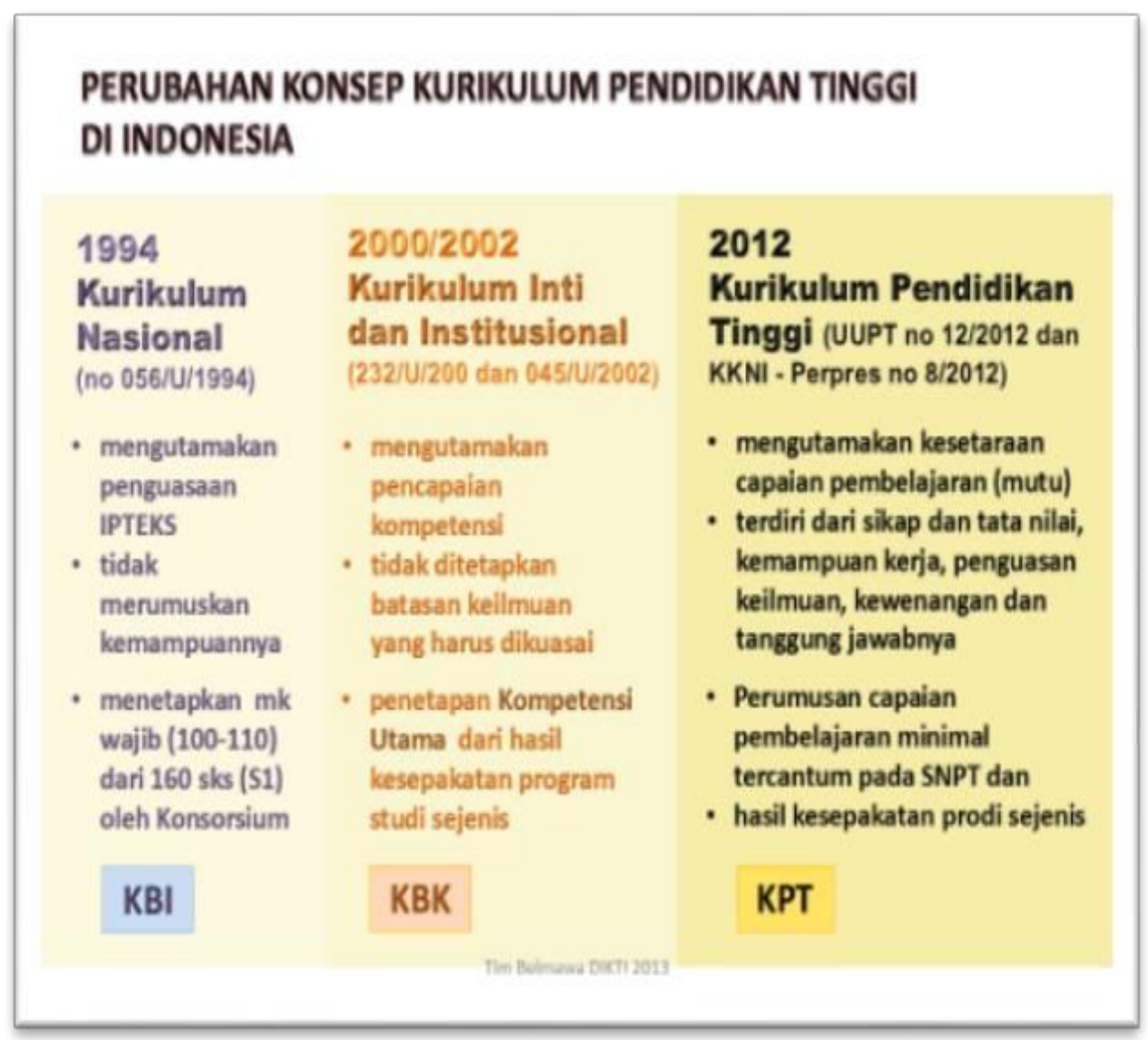

\section{Gambar : Diadaptasi dari Pedoman KKNI Kopertais Wilyah IV Surabaya}

Dalam tujuan dan arah pendidikan yang termaktub dalam SK MENDIKNAS NO. 232/U/2000 Pasal 2 menyebutkan bahwa Pendidikan akademik bertujuan menyiapkan peserta didik untuk menjadi masyarakat yang memiliki kemampuan akademik dalam menerapkan, mengembangkan, memperkaya khazanah ilmu pengetahuan, teknologi atau kesenian untuk meningkatkan kehidupan masyarakat dan memperkaya kebudayaan nasional. ${ }^{2}$

Dalam SK Mendiknas tersebut pada bab IV pasal 7 disebutkan bahwa ada 2 bentuk kurikulum yang menjadi dasar penyelenggaraan program studi yaitu; kurikulum inti, dan kurikulum institusional. Seperti yang termaktub dalam pasal 7 tersebut menerangkan bahwa kurikulum inti merupakan kelompok bahan kajian dan pelajaran yang harus dicakup dalam suatu program studi yang dirumuskan dalam kurikulum yang berlaku secara nasional. Kurikulum ini terdiri atas kelompok rnata kuliah pengembangan kepribadian, kelompok mata kuliah yang mencirikan tujuan pendidikan 
dalam bentuk pencari ilmu pengetahuan dan keterampilan,keahlian berkarya, sikap berperilaku dalam berkarya dan cara bermasyarakat, sebagai persyaratan minimal yang harus dicapai pesertadidik dalam penyelesaian suatu program studi. ${ }^{3}$

Kurikulum institusional merupakan sejumlah bahan kajian dan pelajaran yang merupakan bagian dari kurikulum pendidikan tinggi, terdiri atas tambahan dan kelompok ilmu dalamkurikulum inti yang disusun dengan memperhatikan keadaan dan kebutuhan lingkunganserta ciri khas perguruan tinggi yang bersangkutan. ${ }^{4}$

\section{Metode Penelitian}

Penelitian ini adalah kajian epistimologis dengan menggunakan metode pengumpulan data kualitatif dengan jenis fenominologis. Data dikumpulkan melalui wawancara, observasi dan dokumen. Wawancara dilakukan secara purposive dengan fokus pada program studi PBA STAI Al-Khairat Pamekasan sehingga memudahkan untuk memetakan fokus dan objek penelitian. Informan dari penelitian ini adalah civitas akademika kampus STAI Al-Khairat Pemakasan.

\section{Kurikulum Multikultural di Pendidikan Tinggi \\ Pendidikan Islam}

Dalam dunia Islam, pada hakikatnya Pendidikan Agama Islam bertujuan untuk meningkatkan ketakwaan dan ketaatan kepada Allah SWT. Dalam Pandangan AlGhazali, tujuan dari pada pendidikan Islam adalah mendekatkan diri kepada Allah, dengan tanpa mengharap kepada derajat tertentu/atau kekuasaan, tanpa harus berpikir tanggung jawab yang besar. Tanpa harus berbangga-bangga, riya', pamer karena yang demikian dapat mengakibatkan dan menebar kebencian dan dan kedengkian. Al-Ghazali memandang Pendidikan Islam dari sudut pandang Sufistik, Pendidikan menurut AlGhazali seharusnya menjadi bekal untuk meningkat derajat di hadapan Allah di akhirat kelak. Dan mendapat keluasan kebahagiaan di Surga. Al-Ghazali menyebutkan bahwa bagaimanapun seorang ayah menyelamatkan anaknya dari neraka dunia, maka sebenarnya dia telah menyelamatkan anaknya dari neraka akhirat. Dan

\footnotetext{
${ }^{3}$ Ibid

${ }^{4}$ SK Mendiknas no. 232/u/2000 Bab 2 PAsal 7 tentang kurikulum inti dan kurikulum institusional.
} 
perlindungan/penyelamatan itu dilakukan dengan cara mendidik dan mengajarkan Akhlak yang baik. ${ }^{5}$

Pendidikan Islam berhubungan dengan agama dan dunia, kata al-Ghazali apakah kalian tahu bahwa buah ilmu itu adalah al-Qurbu ilallah (dekat kepada Allah) dan setara bahkan di atas malaikat, ini adalah di akhirat. Adapun di dunia, adalah kesulitan dan beban, dan melaksanakan hukum bagi yang berwenang, dan saling menghormati. Dan tujuan dari pendidikan adalah bahwa ilmu adalah ibadah hati, dan sholat yang rahasia, dan mendekatkan batin kepada Allah SWT, dan mengeluarkan akhlak yang buruk dan menanamkan akhlak karimah. ${ }^{6}$

\section{Pendidikan Islam Multikultural}

Teori E. B. Tylor (bambang Rustanto, 2016). Budaya adalah suatu keseluruhan yang meliputi pengetahuan, kepercayaan, kesenian, moral, keilmuan, hukum, adat istiadat, dan kemampuan yang lain serta kebiasaan yang didapat oleh manusia sebagai anggota keluarga masyarakat. Kemudian Selo Soemardjan, mengatakan bahwa kebudayaan adalah semua hasil karya, rasa dan cipta masyarakat. Sementara Herkovits, menyebutkan bahwa budaya adalah bagian dari lingkungan hidup yang diciptakan oleh manusia. Jadi budaya atau kebudayaan adalah keseluruhan Konsep gagasan, tindakan dan hasil karya manusia dalam kehidupan masyarakat yang dijadikan milik dari manusia dengan belajar. Kebudayaan bisa dikatakan suatu Konsep dalam masyarakat dimana terjadi interaksi antar individu, kelompok dengan kelompok sehingga menimbukan pola tertentu, kemudian menjadi sebuah kesepakatan bersama baik langsung maupun tidak. ${ }^{7}$

Salah satu unsur budaya adalah Agama dan kepercayaan. ${ }^{8}$ Menurut Amin Abdullah, cara yang paling tepat untuk mempertahankan budaya/ tradisi dan identitas keagamaan di atas adalah melalui jalur pendidikan. Hal ini disebabkan karena pendidikan adalah alat yang paling efektif untuk meneruskan, melanggengkan, mengawetkan, dan menjaga tradisi dari satu generasi ke generasi selanjutnya, dari abad yang satu ke abad yang lain. Pendidikan merupakan salah satu media yang paling efektif

\footnotetext{
${ }^{5}$ Muhammad Athiyyah al-Abrosy. At-Tarbiyah al-Islāmiyah wa falasifatihā (Darul Fiqr al-Araby, tt). 225. ${ }^{6}$ Ibid,., 226.

${ }^{7}$ Bambang Rustanto, Masyarakat Multikultural di Indonesia (Bandung: PT Remaja Rosda Karya, 2016), 25-26.

${ }^{8}$ Ibid.., 27.
} 
untuk melahirkan generasi yang memiliki pandangan yang mampu menjadikan keragaman sebagai bagian yang harus diapresiasi secara konstruktif. Sebab, pendidikan bersifat Konsepik dengan tingkat penyebaran yang cukup merata. Lembaga-lembaga pendidikan dari berbagai tingkatan telah tersebar secara luas di berbagai wilayah Indonesia. Oleh karena itu, pendidikan menjadi sarana yang cukup efektif untuk mencapai tujuan ideal ini. ${ }^{9}$

Gusdur mengatakan bahwa kebudayaan sebuah bangsa pada hakikatnya adalah kenyataan yang majemuk atau pluralistic dan multicultural. Maka pertengahan tahun 2002 sebuah jurnal antropologi mengadakan symposium internasional yang bertemakan "Membangun kembali Indonesia yang bhineka Tunggal Ika Menuju Masyarakat Multikultural" Simposium ini menghasilkan konsep penting, bahwa keragaman budaya dalam sebuah komunitas besar (bangsa) merupakan sebuah keniscayaan yang tak bisa terelakkan. $^{10}$

Di antara idealitas keagamaan Islam sebagaimana tertulis dalam al-Qur'an ${ }^{11}$ adalah untuk saling mengenal dan menghormati berbagai budaya, ras, dan agama sebagai suatu realitas kemanusiaan. Akan tetapi pada saat yang sama peta dunia diwarnai konflik akibat SARA. Kesenjangan antara idealitas dan realitas itulah yang perlu dijembatani dengan memberikan pemahaman multikultural dalam proses pendidikan keislaman. Sebagai sebuah konsep, pendidikan multikultural menemukan relevansinya untuk konteks Indonesia. Pendidikan multikultural sejalan dengan semboyan bangsa Indonesia "Bhinneka Tunggal Ika" yang memiliki pengertian bahwa Indonesia merupakan salah satu bangsa di dunia yang terdiri dari beragam suku, ras, budaya, bahasa, dan agama yang berbeda-beda tetapi dalam kesatuan Indonesia. ${ }^{12}$

Banyak pakar yang mendefinisikan Multikultural sesuai dengan pandangan mereka masing-masing. Ada yang mengatakan bahwa multikulturalisme identic dengan dengan keragaman kultural atau kebudayaan. Menurut Parsudi Suparlan (2002) akar kata dari multikulturalisme adalah kebudayaan. Istilah multicultural ini telah terbentuk

\footnotetext{
${ }^{9}$ Achmad Rois, Pendidikan Islam Multikultural Telaah Pemikiran Muhammad Amin Abdullah. Epistemé, Vol. 8, No. 2, Desember 2013, 302.

${ }^{10}$ Choirul Mahfud, Pendidikan Multikultural (Yogyakarta: Pustaka Pelajar, 2015), 90-91.

${ }^{11}$ Q.S. al-Hujurat 13.

${ }^{12}$ Tri Astutik Haryati, Islam Dan Pendidikan Multikultural . Tadrîs. Volume 4. Nomor 2. 2009), 143 144.
} 
suatu ideologi yang disebut multikulturalisme. ${ }^{13}$ Multikulturalisme merupakan paham tentang keragaman budaya $^{14}$. Dalam keragaman inilah mulai lahir pemahamanpemahaman tentang toleransi, kesetaraan, keadilan, kebersamaan, perdamaian dan sejenisnya. Paham-paham ini yang kemudian mempunyai tujuan mulia, yaitu untuk menciptakan sebuah kehidupan yang aman, tentram, damai dan sejahtera serta terhindar dari berbagai konflik yang tak kunjung usai. ${ }^{15}$

Azumardi Azra sebagaimana dikutip Tolchah, menyebutkan bahwa multikulturalisme adalah pandangan dunia yang kemudian dapat diterjemahkan dalam berbagai kebijakan kebudayaan yang menekankan kepada penerimaan terhadap realitas keagamaan, pluralitas, dan multikultural, yang terdapat dalam kehidupan bermasyarakat. ${ }^{16}$ Sementara Parekh, mengutip dari Azra, dalam Tolchah menyebutkan bahwa masyarakat multicultural adalah suatu masyarakat yang terdiri dari beberapa macam komunitas budaya dengan segala kelebihannya dengan sedikit perbedaan konsepsi mengenai dunia. Suatu Konsep arti, nilai, bentuk organisasi sosial, sejarah.,adat serta kebiasaan. ${ }^{17}$

Pandangan Azra di atas kemudian dirincikan secara aplikatif oleh Atho' Muzhar, bahwa multikulturalisme adalah mencakup gagasan, cara pandang, kebijakan, penyikapan dan tindakan oleh masyarakat suatu Negara yang mejemuk dari segi etnis, budaya, agama, dan sebagainya. Namun mempunyai semangat untuk mengembangkan semangat kebangsaan yang sama dan mempunyai kebangsaan untuk mempertahankan kemajemukan tersebut. ${ }^{18}$

Kemudian Ada tiga istilah yang sering digunakan untuk menggambarkan masyarakat yang mempunyai keberagaman tersebut (agama, ras, bahasa, dan budaya yang berbeda) yaitu pluralitas (plurality) ${ }^{19}$, keragaman (diversity), dan multikultural

\footnotetext{
${ }^{13}$ Muhammad Tholhah Hasan, Pengertian Dasar tentang Multikulturalisme dan Pendidikan Multicultural, (Malang : Pascasarjana 3 Unisma), bahan kuliah program doctor PAI Multikultural, 2017. 8.

${ }^{14}$ Mengenai Pandangan Multikulturalisme Merupakan Paham Tentang Keragaman Budaya Baca Scott Lash dan Mike Featherstone (ed.), Recognition And Difference: Politics, Identity,Multiculture (London: Sage Publication, 2002). 2-6

${ }^{15}$ Achmad Rois: Pendidikan Islam Multikultural..,308-309.

${ }^{16}$ Mohammad Tholchah Hasan, Pendidikan Multikulturla...,8

${ }^{17}$ Ibid, 9

${ }^{18}$ Mohammad Tholchah Hasan, Pendidikan Multikulturla...,9.

${ }^{19}$ Apabila merujuk dari wikipedia bahasa Inggris maka definisi pluralisme adalah: "In the social sciences, pluralism is a framework of interaction in which groups show sufficient respect and tolerance of each other, that they fruitfully coexist and interact without conflict or assimilation (Suatu kerangka interaksi
} 
(multicultural). Ketiga ekspresi itu sesungguhnya tidak merepresentasikan hal yang sama, walaupun semuanya mengacu kepada adanya 'ketidaktunggalan'. Inti dari multikulturalisme adalah kesediaan menerima kelompok lain secara sama sebagai kesatuan, tanpa memperdulikan perbedaan budaya, etnik, jender, bahasa, ataupun agama. Apabila pluralitas sekedar merepresentasikan adanya kemajemukan (yang lebih dari satu), multikulturalisme memberikan penegasan bahwa dengan segala perbedaannya itu mereka adalah sama di ruangpublik. ${ }^{20}$

Sehingga dari beberapa pandangan tentang Multikulturalisme tersebut dapat ditarik satu kesimpulan bahwa Multikulturalisme adalah satu pandagan dan paradigm/prinsip untuk memberikan apresisasi terhadap berbagai keanegaraman, agama, suku, etnis, bahasa, sosial meski kita dapat menjaga identitas dan kepribadian kita. Kita dapat hidup berdampingan secara damai dengan mengedepankan nilai toleransi dan saling menghormati dalam keanekaragaman.

Maka jika terminologi multikulturalisme dijadikan landasan dalam dunia pendidikan maka karakteristik pendidikan multikultural terlebih dahulu perlu dibahas pengertiannya. Menurut Fredrick J. Baker (2004: 1) pendidikan multikultural adalah "gerakan reformasi yang didesain untuk mengubah lingkungan pendidikan secara menyeluruh sehingga peserta didik yang berasal dari kelompok ras dan etnik yang beragam memiliki kesempatan yang sama untuk memperoleh pendidikan di sekolah, pendidikan tinggi, dan universitas." Senada dengan pengertian di atas, Francisco Hidalgo, menyatakan bahwa pendidikan multikultural adalah "pembelajaran yang bebas dari rasisme, seksisme, serta bentuk-bentuk dominasi sosial dan intoleran lainnya." Sementara itu, menurut Okado (2005: 1) pendidikan multikultural merupakan "pendidikan yang membantu para peserta didik untuk mengembangkan kemampuan mengenal, menerima, menghargai, dan merayakan keragaman kultural." Pengertian senada dikemukakan oleh Keith Wilson (2005: 1) bahwa pendidikan multikultural adalah "pendidikan yang didesain berdasarkan pembangunan konsensus, penghargaan, dan penguatan pluralisme kultural ke dalam masyarakat yang rasial. ${ }^{21}$

\footnotetext{
yang mana setiap kelompok menampilkan rasa hormat dan toleran satu sama lain, berinteraksi tanpa konflik atau asimilasi/pembiasaan. Achmad Rois: Pendidikan Islam Multikultural...306.

${ }^{20}$ Tri Astutik Haryati, Islam dan Pendidikan Multikultural..,155-156.

${ }^{21}$ Abdullah Aly, Studi Deskriptif Tentang Nilai-Nilai Multikultural Dalam Pendidikan Di Pondok Pesantren Modern Islam Assalaam. (Jurnal Ilmiah Pesantren, Volume I, Nomer 1, Januari-Juni 2015), 11 .
} 
a. Nilai Pendidikan Islam Multikultural

Mengenai Nilai-nilai Multikulturalisme, beberapa nilai disebutkan dalam alQuran dan dapat dijadikan acuan :

1. Al-Musawah (kesetaraan/persamaan)

2. Al-Rahmah (kasih sayang)

3. Hablun min al-Nas (humanis)

4. Al-Musawaroh (Demokrasi/mendahulukan dialog)

5. Al-A'dl (Keadilan)

6. Al-Tasamuh (toleransi)

7. Al-Ta'ruf (kebersamaan)

8. Al-Ta'awun (tolong menolong)

9. As-Salam (kedamaian)

10. Al-Ta'adudiyat (Plural)

11. Al-'Afwu (inklusif)

12. Al-Ikhsan (positive thingking)

13. Al-Amanah (disiplin/jujur)

14. Al-Tanawwu' (keberagaman). ${ }^{22}$

Gusdur (dalam Mun'im 2005) menuturkan bahwa peradaban dunia ini dapat dilestarikan dan dikembangkan dengan baik jika terwujud nilai-nilai multicultural, seperti humanis, toleransi, menghargai, menerima, mengutamakan silaturahim, (dialog) pada semua individu, kelompok organisasi, dan lintas paham keyakinan, menyayangi kaum lemah, dan monoritas, menjaga persatuan, dan perdamaian, mengembangkan budaya, menjaga kearifan budaya lokal dalam masyarakat. ${ }^{23}$ Sedangkan M. Tholhah Hasan menjelaskan bahwa nilai-nilai yang harus ada dalam masyarakat adalah kometmen untuk bisa hidupbersama, saling menghormati, bekerjasama, tolong menolong, gotong royong dalam suasana hidup rukun dan damai. $^{24}$

\footnotetext{
${ }^{22}$ Munif, Multikulturalisme dalam pendidikan madrasah; Nilai, implikasi dan model pengembangan (Surabaya: Imtiyaz, 2016), 42.

${ }^{23}$ Ibid, 91

${ }^{24}$ Mohammad Tholchah Hasan, Pendidikan Multikulturla...,4.
} 


\section{Multikultural dalam Kurikulum Institusional}

McCormic (1983) dalam Thalchah Menyebutkan empat model multicultural dalam konteks pembentukan suatu bangsa, yaitu; Pertama, model melting pot, dalam pengertian peleburan etnisitas dan budaya menjadi sebuah bangsa baru, sehingga ciriciri etnisitas dan budaya lama yang membentuk kesatuan bangsa itu menjadi hilang. Kedua, model assimilation, yaitu suatu pandangan yang membenarkan illiminasi perbedaan-perbedaan yang ada dan membaur dengan kelompok yang dominan. Ketiga, Model Salad Bowi, yang memandang setiap individu atau kelompok dalam suatu masyarakat harus menghormati keragaman kultural yang berasal dari etnis, budaya, agama, bahasa dan dimana wilayah individu dan kelompok berasal. Dan pada saat yang sama mendukung kesepakatan yang telah disetujui bersama untuk bersatu dan saling menghormati dalam satu wadah dan hidup berdampingan secara damai. Bangsa Indonesia mengikuti model ketiga ini dengan semboyan Bhineka Tunggal Ika. Keempat model open nation, suatu pandangan masyarakat terbuka, masyarakat dengan segala keragamannya dibebaskan mengambil cara yang dikehendaki dalam membentuk suatu bangsa. $^{25}$

Model Salad Bowl dalam penerapan pendidikan Multikultural di Indonesia sesuai dengan TAP MPR RI No. VII/MPR/2001 tentang visi Indonesia Masa Depan, bahwa di antaranya menjelang tahun 2020 di identifikasikan adanya beberapa tantangan yang akan dihadapi oleh bangsa dan Negara. Tangtangan-tantangan tersebut adalah :

1. Perlunya pemantapan persatuan bangsa dan kesatuan Negara;

2. Diperlukan Konsep hukum yang adil, supremasi hukum perlu ditegakkan untuk menjamin kepastian hukum, keadilan dan pembelaan hak asasi manusia;

3. Diperlukan Konsep politik yang demokratis;

4. Konsep ekonomi yang adil dan produktif;

5. Konsep sosial budaya yang beradab, ditandai dengan kebebasan berekspresi, tertanamnya nilai universal yang diajarkan setiap agama, dan niali luhur budaya bangsa. Peningkatan kualitas hidup masyatakat melalui mutu pendidikan, pelayanan kesehatan, lapangan kerja yang tersedia, upah yang layak.

6. Sumber daya manusia yang bermutu;

\footnotetext{
${ }^{25}$ Ibid, 11.
} 
7. Dalam menghadapi globalisasi rakyat diberikan ketahanan untuk mempertahankan eksistensinya dan integritas sebagai bangsa dan Negara.

Visi Indonesia 2020 bertujuan mewujudkan masyarakat Indonesia yang religious, bermoral, berprikemanusiaan, bersatu, dan demoktratis, selanjutnya masyarakat adil dan sejahtera, maju dan mandiri, serta mempunyai pemerintahan yang bersih (good government) yang sekaligus menjadi indikator keberhasilan Indonesia 2020. Maka pendidikan multicultural saat ini implementasinya sangat mendesak dalam rangka membangun bangsa Indonesia yang sesuai dengan tiga undang-undang pendidikan yang kita kenal yaitu UU No 4 tahun 1950, (b). UU No 2 tahun 1989 (c). UU No 20 tahun 2003. Yang jika kita cermati dari UU yang mengatur pendidikan nasional yang paling menonjol adalah Sumpah pemuda yang menekankan kesatuan dan persatuan bangsa. ${ }^{26}$

Pendidikan multikultural bukan semata-mata tugas pendidikan formal, tapi tanggung jawab seluruh masyarakat yang memiliki kebudayaan itu. Maka setidaknya ada lima program prioritas pendidikan multikultural sebagai berikut : Lembaga pendidikan sebagai pusat budaya, Pendidikan kewarga negaraan, Kurikulum pendidikan multikultral, Kebijakan perbukaan, Pendidikan guru. ${ }^{27}$

\section{Nilai Multikultural pada Kurikulum Institusional}

Dalam kurikulum institusional STAI Al-Khairat Pamekasan ingin mencetak mahasiswa mampu mengaplikasikan bidang keahlian dan memanfaatkan IPTEKS pada bidangnya dalam penyelesaikan masalah serta mampu beradaptasi terhadap situasi yang dihadapi. Beradaptasi ${ }^{28}$ inilah sebuah nilai multicultural bagaimana mahasiwa harus hidup dan berkembang sesuai dengan situasi yang mereka hadapi. Secara terperinci Mahasiswa dalam kurikulum ini harus mampu hal-hal sebagaimana berikutn:

1. Bertaqwa kepada Tuhan Yang Maha Esa

2. Memiliki moral, etika dan kepribadian yang baik dalam menyelesaikan tugasnya

3. Berperan sebagai warga Negara yang bangga dan cinta tanah air serta mendukung perdamaian dunia

\footnotetext{
${ }^{26}$ H.A.R. Tilaar, Multikulturalisme; Tantangan-Tantangan Global Masa Depan dalam Transformasi Pendidikan Nasional (Jakarta:Grasindo, 2004), 207-213.

${ }^{27}$ Ibid.., 224.

${ }^{28}$ Beradaptasi memerlukan modal, setidaknya 3 modal utama untuk tetap survive (modal ekonomi, modal social, modal simbolik). Baca buku Mufiqur Rahman, survavilitas etnis China di Pamekasan setelah Gerbang Salam (Litbang Pamekasan, 2017), 8.
} 
4. Mampu bekerjasama dan memiliki kepekaan sosial dan kepedulian yang tinggi terhadap masyarakat dan lingkungannya.

5. Menghargai keanekaragaman budaya, pandangan, kepercayaan, dan agama serta pendapat/temuan orisinal orang lain

6. Menjungjung tinggi penegakan hukum serta memiliki semangat untuk mendahulukan kepentingan bangsa dan Negara serta masyarakat luas.

7. Mampu Mengalisis kebutuhan materi bahasa Arab sesuai dengan kebutuhan pasar dan peserta didik.

8. Mampu merancang dan mendesignkurikulum dan bahan ajar yang dibutuhkan dalam pembelajaran bahasa Arab dengan berbagai macam pendekatan dan pola.

9. Mampu mengaplikasikan berbagai macam metodedan strategi pembelajaran di dalam kelas

10. Mampu merancang dan menggunakan media pembelajaran, baik media pembelajaran tekhnologi-trasional maupun media berbasis tekhnologi-modern.

11. Mampu mengaplikasikan konsep manajemen kelas dalam pembelajaran bahasa Arab.

12. Mampu mengaplikan konsep evaluasi atau penilaian dan pengukuran dalam pembelajaran bahasa Arab.

13. Mampu melakukan Penelitian Tindakan Kelas (PTK) sebagai bentuk konsep evaluasi pengembangan pembelajaran.

Nilai multicultural juga terlihat secara jelas dalam struktur kurikulum di bawah ini $:^{29}$

\footnotetext{
${ }^{29}$ Diambil dari kurikulum PBA STAI Al-Khairat Pamekasan, 1 Maret 2018.
} 


\begin{tabular}{|c|c|c|c|c|c|}
\hline No & Semester 1 & Sks & No & Semester 2 & Sks \\
\hline 1. & Pancasila & 2 & 1. & Ulumul Hadits & 2 \\
\hline 2. & Bahasa Indonesia KTI & 2 & 2. & Ulumul Fiqih & 3 \\
\hline 3. & Logika & 3 & 3. & Bahasa Arab 2 & 2 \\
\hline 4. & Bahasa Inggris & 2 & 4. & $\begin{array}{l}\text { Bahasa Arab } \\
\text { Parawisata }\end{array}$ & 3 \\
\hline 5. & Bahasa Arab I & 2 & 5. & MetodeTarjamah & 3 \\
\hline 6. & Pengantar Studi Islam & 3 & 6. & Pengantar Filsafat & 3 \\
\hline 7. & Ulumul Qur'an & 3 & 7. & $\begin{array}{l}\text { Sejarah Peradaban } \\
\text { Islam }\end{array}$ & 3 \\
\hline 8. & Ulumul Hadits & 2 & 8. & $\begin{array}{l}\text { Dunia Islam } \\
\text { Kontemporer }\end{array}$ & 2 \\
\hline 9. & Kepesantrenan & 3 & 9. & IAD/ISD/IBD & 3 \\
\hline 10. & $\begin{array}{l}\text { Kewirausahaan } \\
\text { Pendidikan }\end{array}$ & 2 & & & \\
\hline & Jumlah & 24 & & Jumlah & 24 \\
\hline
\end{tabular}

Pada semester satu dan dua sekurang-kurangnya telah memberikan landasan kurikulum bernilai multicultural pada materi Pancasila, Pengantar Studi Islam, Ulumul quran dan hadis, kepesantrenan. Dan beberapa materi lainnya yang dikaji dengan pendekatan multicultural. Nilai-nilai seperti ; Al-musawah (kesetaraan/persamaan), Alrahmah (kasih sayang), hablunminannas (humanis), Al-musawaroh (demokrasi/mendahulukan dialog), Al-a'dl (keadilan), Al-Tasamuh (toleransi), Al-ta'ruf (kebersamaan), Al-ta'awun (tolong menolong), As-salam (kedamaian), Al-ta'adudiyat (plural), Al-'afwu (inklusif), Al-ikhsan (positive thingking), Al-amanah (disiplin/jujur) telah ditekankan pada setiap materi, terkhusus pada pengantar studi Islam dan kepesantrenan yang memang diajarkan untuk memperkuat pengetahuan mahasiswa terhadap nilai-nilai universalitas, religiusitas dan keummatan/kebangsaan.

Nilai kedisiplinan dan demokrasi dan nilai-nilai multicultural disebut di atas terlihat dalam pemilihan Presiden BEM dan beberapa pemilihan lainnya di Kampus STAI Al-Khairat mengedepankan nilai-nilai yang membawa pada perdamian dan al- 
ikhsan sehingga kampus yang berada di lingkungan Pesantren ini selalu menampilkan sosok ramah tanpa memberikan kesan keangkuhan sama sekali, misalnya dalam kontek multikulturasi pendidikan dalam dimensi geografis, STAI Al-Khairat menerima semua mahasiswa dari berbagai daerah di Indonesia, Dalam dimensi sosial, STAI Al-Khairat menerima diversitas sosial mahasiswa, (seperti Mahasiswa yang tidak mampu secara ekonomi dst.).

STAI Al-Khairat menerapkan Model Salad Bowi, yang memandang setiap individu atau kelompok dalam suatu masyarakat harus menghormati keragaman kultural yang berasal dari etnis, budaya, agama, bahasa dan dimana wilayah individu dan kelompok berasal. Pada saat yang sama mendukung kesepakatan yang telah disetujui bersama untuk bersatu dan saling menghormati dalam satu wadah dan hidup berdampingan secara damai. Karena hingga saat ini jumlah ditemukan sebuh kasus atau percekcokan antar mahasiswa atau dosen sebuah konflik yang bersumber dari keragaman kultural yang berasal dari etnis, budaya, agama, bahasa dan dimana wilayah individu dan kelompok berasal. Meski Mahasiswa datang dari berbagai daerah di Indonesia, tidak menimbukan kegaduhan atau kekerasan atau pelanggaran rasis. Ini dalam kajian multikultural menunjukkan adanya nilai-nilai multikultural yang diterapkan walupun secara eksplisit.

\section{Digitalisasi Kurikulum Multikultural}

STAI Al-Khairat telah melakukan setidaknya tujuh fungsi di era digital yaitu digalakkannya sumber informasi kampus secara massif melalui jejaring sosial, kemudian membangun kreatifitas dengan mendorong mahasiswa untuk mengikuti ajang kreativitas mahasiswa, membangun komunikasi yang baik melalui jejeraing sosial antar mahasiswa dan dosen, dan antar dosen dan karyawan, pembelajaran jarak jauh mengenai pesan-pesan multikultural, memaksimalkan jejaring sosial untuk kepentingan kampus, dan mendorong pertumbuhan usaha kampus, serta memperbaiki pelayanan publik. $^{30}$

Digitalisasi kuriulum adalah upaya membuat kurikulum tersistem dalam sebuah media, karena digital sangat hubungannya dengan media. Kemudian digitalisasi yang dilakukan di STAI Al-Khairat dalam hal pembelajaran di kelas dengan

\footnotetext{
${ }^{30}$ Kemendikbud, Mendidik anak di era digital, ( Jakarta: Kemendikbud, 2017), 8.
} 
memanfaatkan pembelajaran multimedia dengan perangkatnya sehingga mahasiswa melakukan pembelajaran dengan tidak hanya mendengar saja (audio) namun juga langsung mengamati dan merasakan. Bahkan pada prodi lain (ekonomi) misalya melakukan pembelajaran dengan mengikuti wisata pendidikan kepada beberapa objek pelaku ekomoni sehingga mahasiswa tidak hanya belajar di kelas namun juga mereka mengalami (experienced) pembelajaran langsung bersama para pelaku ekonomi.

Kemudian digitalisasi kurikulum multicultural, para dosen secara aktif mendemontrasikan nilai-nilai multikultural nilai-nilai seperti; al-musawah (kesetaraan/persamaan), al-rahmah (kasih sayang), hablunminnaas (humanis), almusawaroh (demokrasi/mendahulukan dialog), al-a'dl (keadilan), al-tasamuh (toleransi), al-ta'ruf (kebersamaan), al-ta'awun (tolong menolong), as-salam (kedamaian), al-ta'adudiyat (plural), al- 'afwu (inklusif), al-ikhsan (positive thingking), al-amanah (disiplin/jujur) secara natural dan sistemik telah hadir di lingkungan kampus. Nilai-nilai tersebut disampaikan baik melalui media kampus (seperti jurnal kampus, majalah dinding dst) juga disampaikan dalam pembelajaran di kelas dengan pendekatan multimedia, sehingga nilai-nilai tersebut dapat dengan mudah dicerna oleh mahasiswa.

Model kurikulum berbasis multikultur di STAI Al-Khairat menerapkan Model Salad Bowl, yang memandang setiap individu atau kelompok dalam suatu masyarakat harus menghormati keragaman kultural yang berasal dari etnis, budaya, agama, bahasa dan dimana wilayah individu dan kelompok berasal. Dan pada saat yang sama mendukung kesepakatan yang telah disetujui bersama untuk bersatu dan saling menghormati dalam satu wadah dan hidup berdampingan secara damai. Karena hingga saat ini belumlah ditemukan sebuh kasus atau percekcokan antar mahasiswa atau antar dosen sebuah konflik yang bersumber dari keragaman kultural yang berasal dari etnis, budaya, agama, bahasa dan dimana wilayah individu dan kelompok berasal. Meski Mahasiswa datang dari berbagai daerah di Indonesia, tidak menimbukan kegaduhan atau kekerasan atau pelanggaran rasis. Kajian multikultural menunjukkan adanya nilainilai multikultural yang diterapkan walupun secara eksplisit.

\section{Penutup}

STAI Al-Khairat setidaknya melalui kurikulumnya telah melakukan dan menerapkan nilai Multikultural. Walaupun Multikultural terlihat Hidden atau 
tersembunyi tidak secara langsung disebutkan secara terminologis dalan konsep maupun dalam pembelajaran. Tapi secara eksplisit atau naturalistik nilai-nilai multikultural ada dan diajarkan bahkan diterapkan dalam sistem kehidupan mahasiswa sehari-hari. Secara silabi/kurikulum pendidikan nilai multikultural hampir diajarkan pada tiap semester pada setiap kajian keagamaan, seperti pengantar studi islam, tafsir, hadist, dan akhlak tasawwuf. Nilai-nilai seperti; al-Musawah (kesetaraan/persamaan), al-rahmah (kasih sayang), hablunminannas (humanis), al-musawaroh (demokrasi/mendahulukan dialog), al-a'dl (keadilan), al-tasamuh (toleransi), al-ta'ruf (kebersamaan), al-ta'awun (tolong menolong), as-salam (kedamaian), al-ta'adudiyat (plural), al- 'afwu (inklusif), al-ikhsan (positive thingking), al-amanah (disiplin/jujur) secara natural dan sistemik telah hadir di lingkungan kampus. 


\section{Daftar Pustaka}

Aly, Abdullah. Studi Deskriptif Tentang Nilai-Nilai Multikultural Dalam Pendidikan Di Pondok Pesantren Modern Islam Assalaam. Jurnal Ilmiah Pesantren, Vol. I. No1. Januari-Juni 2015.

Athiyyah al-Abrosy, Muhammad. At-Tarbiyah Al-Islāmiyah Wa Falasifatihāa . Darul Fiqr al-Araby, tanpa tahun.

Haryati,Tri Astutik.Islam Dan Pendidikan Multikultural. Tadrîs. Vol 4. No 2. 2009.

Lash, Scott dan Featherstone, Mike. 2002. Recognition And Difference: Politics, Identity, Multiculture. London: Sage Publication.

Mahfud, Choirul. 2015. Pendidikan Multikultural. Yogyakarta: Pustaka Pelajar,

Munif, 2016. Multikulturalisme dalam Pendidikan Madrasah; Nilai, Implikasi dan Model Pengembangan. Surabaya: Imtiyaz.

Rahman, Mufiqur. 2017. Kerukunan dan Survavilitas Masyarakat Multi Etnis dan Agama di Pamekasan. Bapedda, Pamekasan

Rois, Achmad. Pendidikan Islam Multikultural Telaah Pemikiran Muhammad Amin Abdullah. Epistemé, Vol. 8, No. 2, Desember. 2013

Rustanto., Bambang. 2016. Masyarakat Multikultural di Indonesia. Bandung: PT Remaja Rosda Karya.

SK Mendiknas no. 232/u/2000 Bab 2 PAsal 2 tentang tujuan dana rah Pendidikan.

SK Mendiknas no. 232/u/2000 Bab 2 PAsal 7 tentang kurikulum inti dan kurikulum institusional.

Tholhah Hasan, Muhammad. 2017. Pengertian Dasar tentang Multikulturalisme dan Pendidikan Multicultural. Malang: Pascasarjana 3 Unisma. Bahan kuliah program doctor PAI Multikultural.

Tilaar, H.A.R. 2004. Multikulturalisme; Tantangan-Tantangan Global Masa Depan dalam Transformasi Pendidikan Nasional. Jakarta:Grasindo

Tim, Pedoman penyusunan KKNI Kemenag Diktis Kopertais Wilyah IV Surabaya. 